\title{
Tilviksrannsókn á innleiðingu straumlínustjórnunar hjá framleiðslufyrirtæki
}

\begin{abstract}
Pórður Víkingur Friðgeirsson
thordurv@ru.is

Greinin barst 21. júní 2016.

Sampykkt til birtingar 9. maí 2017.

Straumlínustjórnun (e. lean management) er umtalað og vinsælt stjórnunarform. Tilgangur pessarar rannsóknar er að kanna hvernig innleið̇ing straumlínustjórnunar gekk fyrir sig hjá meðalstóru framleiðslufyrirtæki (Nóa Síríusi h.f ) með tilliti til priggja rekstarpátta p.e.:Vörugæða, starfsánægju og flæði. Rannsóknin er tilviksrannsókn sem framkvæmd var með eigindlegum rannsóknaraðferðum í formi viðtala við stjórnendur og almenna starfsmenn fyrirtækisins. Niðurstöður leiða í ljós að marktæk breyting hefur orðið á tveimur páttum, starfsánægju og flæði en rannsóknin leiðir hins vegar ekki ljós að vörugæði hafi aukist eftir að fyrirtækið hóf innleiðingu straumlínustjórnunar. Niðurstöður rannsóknarinnar benda til pess að helstu hindranir í veginum á innleiðingu straumlínustjórnunar hjá Nóa Síríusi hafa einkum snúiò eftirfarandi páttum; pjálfun og pekkingu starfsfólks, skuldbindingu allra stjórnenda við innleiðinguna og pekkingu peirra á aðferðafræði straumlínustjórnunar og loks upplýsingaflæði innan fyrirtækisins.
\end{abstract}

Dr. Pórður Víkingur Friðgeirsson ${ }^{\mathrm{a}}$ og Magnús Bollason ${ }^{\mathrm{b}}$

aTækni- og verkfræðideild Hăskólans í Reykjavik , Menntavegi 1, 101 Reykjavík

b Nói Síríus hf., Hesthálsi 2-4, 110 Reykjavik
Lykilorð: Straumlínustjórnun, framleiðslufyrirtæki, matvælaframleiðsla, vörugæði, starfsánægja.
The purpose of this study is to examine Lean implementation at an manufacturing company. Three of the main factors that prompted the company to undertake the Lean journey are product quality, employee satisfaction and flow. This is a case study conducted with qualitative research methods and analysis of company data. Semi-structured interviews were conducted with employees that were purposively chosen for the task. Company data was also be studied for numerical results relating to the study. Primary results indicate that a significant change has occurred in two of the three factors measured. Flow and employee satisfaction have both improved. The study does not indicate that product quality has improved in regard to the Lean implementation. The results also show that the main obstacles in the Lean implementation are employee training, company culture and internal flow of information.

Keywords: Lean, manufacturing SMEs, food production, product quality, flow, employee satisfaction

\section{Inngangur}

Straumlínustjórnun (lean management) er orðin vel pekkt hugmyndafræði sem ryður sér sífellt meira til rúms á meðal fyrirtækja hvort sem er í framleiðslu, pjónustu eða annars konar starfsemi. Markmið fyrirtækja með pví að innleiða hugmyndafræði straumlínustjórnunar er að auka samkeppnishæfni sína í sífellt kröfuharðara umhverfi. Í mörgum greinum í framleiðsluiðnaði, sérstaklega í Bandaríkjunum má segja að straumlínustjórnun sé orðin stjórnunarlegt viðmið (Liker og Morgan, 2006). Lág framleiðni og minnkandi samkeppnishæfni evrópskra fyrirtækja í matvælaiðnaði í samanburði við asísk og bandarísk fyrirtæki hefur vakið athygli Evrópusambandsins sem hratt af stað sérstöku verkefni til að reyna að bæta úr pví (Commission of the European Communities, 2005). Ýmsar rannsóknir benda til pess að straumlínustjórnun sé gód leið til pess að bæta samkeppnisstöðu framleiðslufyrirtækja. (Dora et al. 2013). Lág framleiðni í íslensku atvinnulífi í samanburði við mörg önnur lönd (Jacobsen, 2013) hefur pótt áhyggjuefni og til að bregðast við pví hafa mörg íslensk fyrirtæki á undanförnum árum innleitt straumlínustjórnun að meira eða minna leyti. Eitt af peim fyrirtækjum sem hafa tileinkað sér hugmyndafræði straumlínustjórnunar og innleitt hana í starfsemi sína er Nói Síríus hf. Í pessari rannsókn er leitast við að greina hvernig innleiðing straumlínustjórnunar hefur gengið fyrir sig hjá fyrirtækinu.

\section{Rannsóknarspurning og rannsóknarmarkmið}

Straumlínustjórnun stefnir að pví að unnið sé eftir sem skilvirkustum ferlum og aðferðum sem hámarka nýtingu á framleiðslutækjum, fólki og fjármagni. Pað á að leiða til pess að fyrirtækið skili betri vörum og pjónustu til viðskiptavina sinna á sem stystum tíma með sem minnstum tilkostnaði. Pessu markmiði er náð með pví að koma auga á og reyna að útrýma sóun í ferlum fyrirtækisins (Hines og Rich, 1997).

Í pessari tilviksrannsókn er leitað svara við eftirfarandi spurningu:

Hvernig geta lítil og meðalstór framleiðslufyrirtæki nýtt sér aðferðafræði straumlínustjórnunar til að auka samkeppnishæfni sína?

Markmið rannsóknarinnar er að gera aðgengilegar upplýsingar um innleiðinguna pannig að pær geti gagnast fyrirtækjum sem hafa áhuga á innleiðingu straumlínustjórnunar.

\section{Fræðileg nálgun}

Straumlínustjórnun er annars vegar hugmyndafræði (Holweg, 2007) og hins vegar safn ýmissa aðferða og verkfæra en hugmyndafræðin og aðferðirnar verða alltaf að vinna saman til að árangur náist (Liker og Morgan, 2006). Allt frá pví að Taiichi Ohno setti fram Toyota Production system á sjötta áratug síðustu aldar hafa aðferðirnar og hugmyndafræðin verið í sífelldri próun enda eftir miklu að slægjast með réttri forgangsröðun. Melton (2005) sýndi fram á að 5\% aðgerða auka virði vörunnar með beinum hætti fyrir viðskiptavini, að 35\% aðgerða eru nauðsynlegar aðgerðir en auka pó ekki virði og að 60\% aðgerða skapa ekkert virði fyrir viðskiptavini.

Helsta leiðin til að lækka kostnað og auka virði er að freista pess að minnka sóun með pví að fækka peim aðgerðum sem skapa ekki virði fyrir viðskiptavini fyrirtækisins. Í bók Womack og Jones, Lean thinking (2003) eru fimm grundvallaratriði straumlínustjórnunar dregin saman en pau eru: (1) skilgreina virði í augum viðskiptavinarins, (2) koma auga á allar pær aðgerðir sem parf að framkvæma til að koma vörunni til viðskiptavinarins og útrýma peim aðgerðum sem ekki skapa virði, (3) skapa samfellt flæði, (4) láta kröfur viðskiptavina "toga" vöruna í gegn um ferlið og (5) leita fullkomnunar með stöðugum umbótum (Womack og Jones, 2003). Fyrirtæki purfa að ná tökum á öllum pessum páttum til að geta innleitt straumlínustjórnun með árangursríkum hætti í starfsemi sína.

Eitt af vandamálunum við sóun er pað að erfitt er að hafa yfirsýn yfir umfang hennar vegna pess að hún er ekki mæld eða skráð sem slík í bókhaldi fyrirtækja (Dahlgaard og Dahlgaard-Park, 2006). Straumlínustjórnun miðar pannig að pví að greina vandamál í ferlum fyrirtækisins sem valda sóun og draga pau upp á yfirborðið til að gera pau sýnileg. Síđan er leitast við að komast fyrir rót vandans og endurbæta ferlana til að koma í veg fyrir að vandamálin komi upp aftur. Með pessum aðferðum straumlínustjórnunar geta fyrirtæki aukið framleiðni, bætt vörugæði, lækkað kostnað og par með aukið virði 
vara og pjónustu til viðskiptavina sinna (Bhasin og Burcher, 2006). Í seinni tíð hefur pó áherslan víđa færst frá pví að einblína einungis á sóun og kostnað yfir í pað að nýta straumlínustjórnun til pess að auka virði eða skynjað virði vörunnar/pjónustunnar fyrir viðskiptavininn. pað er hægt að gera t.d. með pví að bæta við vöruna eiginleikum sem auka virðið fyrir viðskiptavini, en fjarlægja jafnframt eiginleika sem auka pað ekki (Hines, Holwe, og Rich, 2004).

Straumlínustjórnun snýr eins og ádur sagði ekki eingöngu að hugmyndafræði og fyrirtækjamenningu. Hún inniheldur líka ýmsar aðferðir sem hægt er að velja úr til að aðstoða við innleiðingu, og með pví að velja réttu aðferðirnar er hægt að aðlaga hugmyndafræðina að öllum fyrirtækjum, bæði stórum og smáum. Aðferðirnar styðja flestar við hugmyndafræðina um stöðugar umbætur og eru ýmist til pess að draga úr sóun eða auka virði fyrir viðskiptavini á annan hátt. Verkfærin sem slík eru pó til lítils gagns ef skilningur á hugmyndafræði straumlínustjórnunar er ekki fyrir hendi og fyrirtækjamenningin styður ekki við innleiðingu og notkun peirra (Bhasin og Burcher, 2006). Fræðsla og pjálfun allra starfsmanna er grundvöllur fyrirtækjamenningar sem leiðir til valdeflingar allra pátttakenda í ferlinu til að peir geti unnið með verkfærin á skilvirkan hátt (Dahlgaard og Dahlgaard-Park, 2006).

Hugmyndafræðin um að greina sóun í virðisstraumum (value stream) og útrýma henni í peim tilgangi að auka samkeppnishæefni fyrirtækja var próuð af Ohno og Shiego Shingo og var fyrst innleidd innan Toyota og tekur til sjö prepa (Hines \& Rich, 1997): (1) Offramleiðsla p.e. pegar framleitt er meira en parf. Petta er oft skilgreint sem alvarlegasta sóunin, (2) bið p.e. sá tími sem fer í bið hjá starfsmönnum á milli verkefna eða eftirlit með sjálfvirkum tækjum. Varan er einnig í bið pegar ekki er verið að flytja hana eða vinna við hana, (3) flutningur p.e. að flytja vöru á milli svæða bætir engu virði við hana fyrir viðskiptavini og eykur jafnframt hættu á skemmdum og tekur tíma frá virðisaukandi aðgerðum, (4) ofvinnsla p.e. pegar að vara verið ofunnið vegna pess að ferlum eða ástandi búnaðar er ábótavant, (5) birgðir sem binda fjármuni og taka pláss sem leiðir til kostnaðar, (6) hreyfing p.e. ónauðsynleg hreyfing starfsmanna og tækja skapar ekki virði og er pví sóun og (7) gallar sem kalla á lagfæringar, endurvinnslu eða förgun- sem skapar kostnað og skapar ekkert virði. Stundum er bætt við áttundu tegund sóunar sem er vannýttur mannauður eða vannýttir hæfileikar (Womack og Jones, 2007).

Virðisstraumur inniheldur allar aðgerðir í ferlinu sem parf til að framleiða vöru og koma henni til viðskiptavinar (Womack og Jones, 2003) hvort sem pær aðgerðir eru virðisaukandi eða ekki (Abdulmalek og Rajgopal, 2006). Virðisstraumurinn hefst með hráefninu og endar hjá viðskiptavininum og nær jafnt yfir yfir flæði á vörum og upplýsingum (Abdulmalek og Rajgopal, 2006). Kortlagning virðisstrauma (value stream mapping) er grunnur pess að greina tækifæri til pess að eyða sóun, auka virðisaukandi aðgerðir og bæta flæði í ferlum fyrirtækja (Chiarini, 2013). Með pví að greina og setja upp á sýnilegan hátt flæði vörunnar frá upphafi til enda í gegn um fyrirtækið er hægt að draga fram hvaða aðgerðir eru virðisaukandi og hvaða aðgerðir eru pað ekki (Abdulmalek og Rajgopal, 2006). Við kortlagningu á virðisstraumi er leitast við að greina hvaða eiginleikar og pættir vörunnar eða pjónustunnar hafa raunverulega virði fyrir viðskiptavininn. Síðan eru fundnar leiðir til pess að bæta og breyta ferlinu og nýtt framtíðarferli teiknað upp (Abdulmalek og Rajgopal, 2006). Pegar virðisstraumar eru kortlagðir kemur nánast alltaf fram mikil sóun í ferlinu (Womack og Jones, 2003) og með kortlagningunni næstyfirsýn yfir heildarmyndina ístað pess að einblína á einstaka pætti í ferlinu. Pað skapar sameiginlega sýn á ferlið sem leiðir til betri ákvarðanatöku við endurbætur á virðisstraumnum (Abdulmalek og Rajgopal, 2006).

Eitt af grundvallaratriðum straumlínustjórnunar eru stöðugar umbætur (Womack og Jones, 2003). Kaizen er japanska orðið yfir umbætur og oft er pví haldið fram í skrifum um stjórnun að Kaizen og pátttaka almennra starfsmanna í umbótaverkefnum sé lykillinn að peim árangri sem japanskur framleiðsluiðnaður hefur nád (Brunet og New, 2003).

$5 S$ aðferðin er aðferð sem oft er innleidd snemma í ferlinu hjá fyrirtækjum við innleiðingu straumlínustjórnunar. $5 \mathrm{~S}$ er aðferð til pess að auka framleiðni og minnka sóun með pví að hafa allt í röð og reglu og á sínum stað (Bayo-Moriones et al. 2010). Í Japan er gjarnan litið á á $5 \mathrm{~S}$ sem heimspekilega hugmyndafræði en á vesturlöndum er litið á 5S sem aðferðafræði eða verkfæri i straumlínustjórnun (Bayo-Moriones et al. 2010). Oft er litið til 5S sem forsendu fyrir pví að skapa umhverfi stöðugra umbóta innan fyrirtækja. (Bayo-Moriones et al. 2010).

Sýnileg stjórnun (visual management) er samansafn ýmissa aðferða til að auka yfirsýn stjórnenda og starfsmanna yfir starfsemina. Leiðirnar eru misjafnar en markmiðið er alltaf hið sama sem er að gera sem flesta pætti starfseminnar sýnilega fyrir alla og virkja bæði starfsfólk og stjórnendur til pátttöku í umbótastarfinu (Slack, Chambers, og Johnston, 2010). Algeng aðferð eru svokallaðar VMS (Visual management system) töflur. Pær geta verið settar upp með ýmsum hætti og innihaldið bæði mælingar á einstökum páttum starfseminnar og verkefni sem er verið að vinna að (Liker og Morgan, 2006

Straumlínustjórnun var upphaflega kölluð Just in time pegar hugmyndafræðin barst til annarra landa frá Japan (Slack, Chambers, og Johnston, 2010). Markmiðið með JIT er að framleiða einungis vörur eftir pörf og einungis í pví magni sem pantað er hverju sinni. Petta er gert til pess að koma í veg fyrir birgðasöfnun í ferlinu og stytta afhendingartíma.

Gemba er japanska orðið yfir staðinn sem verðmætin verða til eða vinnan fer fram (Chiarini, 2013). Gemba ganga er pað kallað pegar æðstu stjórnendur gera sér ferð á pessa staði, kynna sér hvaða starfsemi er í gangi hverju sinni, hvernig hún fer fram og ræða við starfsmenn.

SMED (single-minute exchange of die) aðferðafræðin var próuð af Shigeo Shingo í lok sjötta áratugar síðustu aldar til að stytta pann tíma sem tekur að skipta á milli mismunandi afurða í framleiðslutækjum. Toyota var einna fyrst til að nýta sér aðferðafræðina með góðum árangri (Chiarini, 2013). Gjarnan er eingöngu litið á SMED aðferðafræðina sem styttingu á uppsetningatíma í framleiðsluvélum pegar verið er að skipta um framleiðsluvöru en pað er pó aðeins hluti af pví sem SMED aðferðafræðin snýst um. Aðferðinni er gjarnan skipt ífjögur stig: (1) Skilgreining á ytri og innri uppsetningu og undirbúningi, (2) umbreyting á eins mörgum innri uppsetningapáttum og mögulegt er yfir í ytri pætti, (3) umbætur á innri uppsetningu og (4) umbæur á ytri uppsetningu (Chiarini, 2013).

Kanban er kerfi til að skapa tog í gegn um framleiðsluferilinn og koma pannig í veg fyrir offramleiðslu. (Chiarini, 2013) Petta er framkvæmt pannig að hvert stig í ferlinu kallar á gangsetningu á næsta stigi á undan. Pannig er framleiðsla ekki gangsett fyrr en pörf er á og innri birgðasöfnun verður pví ekki til í framleiðsluferlinu. (Chiarini, 2013).

Heijunka er leið til pess að jafna út álagi á framleiðslutækin í kerfi sem er með blandaða framleiðslu ásamt pví að koma í veg fyrir birgðasöfnun inni í kerfinu. Heijunka er í samræmi við pá hugmyndafræði að framleiðsla eigi eingöngu að mæta pöntunum frá viðskiptavinum og sveiflur á markaðinum eigi ekki að leia til aukinnar birgðasöfnunar (Coleman og Vaghefi, 1994). Sá árangur sem hægt er að ná fram með Heijunka er (1) lágmörkun heildarbirgða, (2) lágmörkun nauðsynlegrar framleiðslugetu bæði í tækjabúnaði og mannafla og (3) styttri afhendingartími á vöru til viðskiptavinar (Coleman \& Vaghefi, 1994).

Loks má geta um Flæði (flow) sem til dæmis Womack og Jones (2003) telja eitt af eitt af grundvallaratriðunum í hugmyndafræði straumlínustjórnunar. Par kemur fram að ekki er einungis nóg að 
útrýma sóun og staðla verklag. Pað parf einnig að tryggja að gott flæði sé í gegn um virðiskeðjuna allt frá aðföngum til viðskiptavinar.

Ekki hafa verið gerðar ýkja margar rannsóknir á innleiðingu straumlínustjórnunar í íslenskum fyrirtækjum. Pó má nefna rannsóknir Vilborgar Hannesdóttur (2009), Snorra Fannars Gunnlaugssonar (2013), Ólafar Árnadóttur (2010) og Bynju B. Gröndal (2013). Erlendis hefur innleiðing straumlínustjórnunar verið talsvert rannsökuð hjá framleiðslufyrirtækjum enda á hugmyndafræðin uppruna sinn að rekja til framleiðslufyrirtækja. Mætti par nefna pekktar rannóknir Achanga et al. (2006), Dora et al. (2012) og (2013) og Worley og Doolen (2006) en pessar rannsóknir leiddu í ljós umtalsverð jákvæð áhrif á margvíslega pætti rekstrarins.

\section{Um fyrirtækið}

Nói Síríus er framleiðslu og innflutningsfyrirtæki sem framleiðir fjölmargar tegundir af sælgæti og flytur einnig inn og dreifir sælgæti og morgunkorni. Fyrirtækið er með verksmiðju og söludeild ásamt skrifstofum og vöruhúsi í Reykjavík en starfrækir einnig söluskrifstofu á Akureyri. Heildarvelta fyrirtækisins er um prír milljarðar á ári. Í verksmiðjunni eru árlega framleidd um 1.800 tonn af sælgæti og er fjöldi framleiddra vörunúmera um 300. Starfsmannafjöldi er um 150 og par af starfa um 100 á framleiðslusviði. Verksmiðjunni er skipt upp í sex deildir par sem ýmist fer fram framleiðsla eða pökkun (www.noi. is, án dags.).

\section{Aðferðafræði}

Rannsóknin er fyrirbærafræðileg par sem leitast er við að finna pemu í gögnunum sem fást með viðtölum við viðmælendur og greina pannig reynslu peirra af fyrirbærinu sem er til rannsóknar (Sigríour Halldórsdóttir, 2013). Pátttakendur voru pví valdir með markmiðsúrtaki (purposive sampling) en pá eru valdir viðmælendur sem best pykja henta markmiði rannsóknarinnar (Katrín Blöndal og Sigrí̉ur Halldórsdóttir, 2013). Tekin voru viðtöl við sex starfsmenn með eigindlegum rannróknaraðferðum sem hafa tekið pátt í innleiðingu straumlínustjórnunar hjá fyrirtækinu frá upphafi og höfðu pví samanburð á aðstæðum bæði fyrir og eftir að innleiðingin hófst. Pess var gætt að velja góða fulltrúa starfsmanna með næga pekkingu og yfirsýn yfir innleiðinguna til að fá nægilega mettun (saturation) í peim tilgangi að tryggja gæði rannsóknarinnar (Sigríður Halldórsdóttir og Sigurlína Davídsdóttir, 2013). Viðmælendur voru konur og karlar á ólíkum aldri sem starfa í mismunandi deildum innan fyrirtækisins. Pátttakendur voru bæði stjórnendur og almennir starfsmenn. Viðtölin voru svokölluð hálfstöðluð viðtöl (semi structured interviews) sem henta vel par sem að ætlunin er að ná fram skilningi á reynslu viðmælenda frá peirra sjónarhóli (Helga Jónsdóttir, 2013).

Rannsóknin er tilviksrannsókn (Case study) sem er heppileg aðferð til að skoða raunveruleg tilvik og aðstæður (Rúnar Helgi Andrason og Ársæll Már Arnarsson, 2013).

Rannsakandistarfarhjáfyrirtækinuogpvíereinnigumstarfendarannsókn að ræða (Kristín Pórarinsdóttir og Rúnar Sigpórsson, 2013)

Pau gögn sem fengust meðviðtölum við pátttakendur rannsóknarinnar voru kóðuð með svokallaðri opinni kóðun (Unnur Guðrún Óttarsdóttir, 2013) til að koma auga á pemu í gögnunum en með kóðun viðtala er hægt að flokka saman sameiginlegt efni til að auðvelda greiningu (Kristín Björnsdóttir, 2013). Notast var við samleitandi snið (convergient parallell design) par sem að niðurstöður viðtala og greining á fyrirliggjandi gögnum eru tengdar saman áður en niðurstöður eru túlkaðar (Sigurlína Davíosdóttir og Anna Ólafsdóttir, 2013)

Til vinna gegn hlutdrægni pátttakenda og auka áreiðanleika niðurstaðna var notast við margprófun gagna (data triangulation) en pá eru viðmælenda voru borin saman við fyrirliggjandi gögn í peim tilgangi að auka réttmæti rannsóknarinnar (Robson, 2011).

\section{Framkvæmd og Niðurstöður}

Við úrvinnslu gagnanna sem fengust með viðtölum við pátttakendur voru viðtölin kóðuð til að draga fram pemu sem tengjast viðfangsefninu. í pessum kafla eru svör viðmælenda greind eftir kóðun viðtala var niðurstöðunum skipt niður í fjögur pemu sem tengjast rannsóknarspurningunni. Pemun eru eftirfarandi: (1) Innleiðing straumlínustjórnunar, (2) áhrif straumlínustjórnunar á vörugæði, (3) áhrif straumlínustjórnunar á starfsánægju og (4) áhrif straumlínustjórnunar á flæði.

Innleiðing straumlínustjórnunar hjá fyrirtækinu hófst fyrir alvöru árið 2010 með sampykki stjórnar á tillögu forstjóra um að pað yrði stefna fyrirtækisins að vinna samkvæmt hugmyndafræði straumlínustjórnunar. Í upphafi voru innleiddar VMS töflur hjá framkvæmdaráđi fyrirtækisins og skömmu síđar hjá fleiri deildum. Skömmu síðar var stigið næsta skref í innleiðingunni og pá var framkvæmt eitt mjög stórt Kaizen verkefni par sem að fulltrúar allra deilda og allir stjórnendur endurhönnuðu áætlanaferli fyrirtækisins allt frá innkaupum á hráefni og umbúđum og til sölu og afhendingar til viðskiptavina. Áætlanaferlið var í framhaldinu skilgreint sem kjarnaferli fyrirtækisins sem knýr alla starfsemina áfram. Petta verkefni skilaði fyrirtækinu miklum árangri, bæði hvað varðar pjónustu við viðskiptavini og ekki síður varðandi samskipti og boðleiðir innanhúss. Mikið vantaði á í upphafi að fyrirtækjamenningin styddi við innleiðinguna og eins var stuðningur allra stjórnenda ekki fyrir hendi. Pekking innan fyrirtækisins á straumlínustjórnun var nánast engin nema hjá hluta æðstu stjórnenda. Í raun og veru voru fyrstu skrefin pannig að verið var að preifa á verkfærunum og sjá hvaða árangur næðist af pví að innleiða pau í litlum skrefum.

Pað voru klárlega ekki allir tilbúnir í svona miklar breytingar og pað var líka alveg greinilegt að sumir ætluðu ekki að standa pessu veseni og bara að bíða eftir pví að petta liði hjá eins og allt hitt sem var svosem búið að prófa áđur í einhverjum stjórnunarpælingum og ekki gengið upp.

Fengin var ytri ráðgjafi til að leiða innleiðinguna.Hún fékk víðtækt umboð forstjóra og lét mikið til sína taka innan fyrirtækisins. Hún stýrði Kaizen viðburðum, innleiddi VMS töflur ásamt pví að stjórna fræðslu og pjálfun starfsmanna varðandi straumlínustjórnun. Petta setti aukinn kraft í innleiðinguna en gerði pað líka að verkum að stjórnendur purftu ekki að stíga inn af eins miklum krafti og annars hefði verið krafist af peim. Einnig skapaði föst viðvera og óljóst hlutverk ráđgjafans nokkra óvissu meðal starfsfólks.

Pað var nú bara pannig á tímabili eins og (rádgjafinn) réði bara öllu i fyrirtækinu. Fólk vissi einhvern vegin ekki alveg hvert hennar hlutverk var og af hverju hún virtist fá að ráða öllu pví sem hún vildi ráða og hún gæti bara vaðið inn í allar deildir og sett út á hvernig við vorum að vinna vinnuna okkar.

Mikið vantaði upp á að pekking stjórnenda á straumlínustjórnun og verkfærunum sem verið var að innleiða væri næg sem gerði pað að verkum að hlutverk peirra í innleiðingunni var ekki nægilega skýrt og peir voru pví ekki allir í pví leiðtogahlutverki sem peir hefou átt að vera við að kynna aðferðirnar gagnvart starfsmönnum og leiða breytingarnar. Starfsmenn fundu fyrir pessu og petta dró að einhverju leyti úr trúverðugleika stjórnenda gagnvart starfsmönnum í upphafi innleiðingarinnar og hægði á innleiðingarferlinu.

раð hefði klárlega verið betra gagnvart starfsfólkinu ef framkvæmdarádið hefði keyrt dæmið áfram með hjálp (ráðgjafans) í staðinn fyrir að (ráðgjafinn) drægi (pá) áfram. Ég meina pað var eins og enginn vissi neitt um hvað petta snérist og pað var bara allt í einu einhver kona utan úr bæ farin að stýra fundunum sem að $(X)$ átti að stýra og hann sat bara með okkur hinum og fattaði ekki neitt frekar en við hin. 
Smátt og smátt komst meira jafnvægi á innleiðingarferlið og viðhorf starfsmanna breyttust bæði til innleiðingarinnar og rádgjafans. Vilji starfsmanna til að nýta sér VMS töflurnar í umbótastarfi jókst og árangurinn jókst í samræmi við pað.

Раð var oft alveg ferlega erfitt аð standa í pessu sérstaklega töflufundirnir í byrjun, peir voru nú ekki alltaf gæfulegir og maður sá ekki alltaf hvert hún var að fara en pegar maður horfir til baka sér maður að hún vann auðvitað alveg ótrúlegt starf að snúa skútunni á rétta braut.

Innleiðing á VMS töflunum gekk upp og ofan til að byrja með. Framkvæmdaráðið var fyrst til að innleiða VMS töflu hjá sér og gekk pað hægt í byrjun en með með aðstoð ráđgjafans gekk pað sífellt betur og einhverjir stjórnenda voru hrifnir af hugmyndafræðinni en aðrir sídur. Öllum deildum í fyrirtækinu var svo í framhaldinu gert að tileinka sér sjónræna stjórnun og setja upp VMS töflur. Pessi verkefnastjórnunarpáttur er enn notaður í umbótastarfinu og virkar vel. pegar verkefni er sampykkt er pað síðan rekið á töflunni par sem að ábyrgðarmenn eru skilgreindir og aðgerðir tímasettar.

Hægt og rólega fóru starfsmenn sî̉an að átta sig á kostum sýnilegrar stjórnunar, mótstaðan minnkaði eftir pví sem árangurinn kom betur í ljós og sífellt fleiri starfsmenn lærðu að meta VMS töflurnar. Nú eru starfræktar yfir 20 virkar VMS töflur í fyrirtækinu og algengt er að tímabundin teymi sem stofnuð eru um einstök verkefni noti VMS töflur sem verkefnastjórnunartæki.

Fyrst skildi enginn neitt í pessum töflum. Maður hafði pað á tilfinningunni stundum аð раð væri verið аð búa til verkefni bara til аð hafa eitthvað í gangi á töflunum. Раð hefði purft að kynna okkur miklu betur hver væri raunverulega pælingin á bak við petta töfludæmi. Daglegu fundirnir skila miklu meira. Allur hópurinn hittist strax í upphafi dagsins og allir vita nákvæmlega hvað er í gangi.

Notkun á VMS töflum og daglegir jafnt sem vikulegir fundir með aðstoð peirra eru nú orðnar eðlilegur páttur í starfseminni hjá fyrirtækinu og fjöldi starfsmanna notar pær sem eðlilegt og sjálfsagt hjálpartæki við verkefnastjórnun og upplýsingagjöf á hverjum degi. Fundir eru daglega, stuttir og hnitmiðaðir og skilningur starfsfólks og árangur af sýnilegu stjórnuninni hefur aukist jafnt og pétt.

Mikil breyting hefur orðið á vinnubrögðum innan fyrirtækisins almennt og viðhorfi starfsmanna til peirra aðferða straumlínustjórnunar sem notaðar eru og menning stöðugra umbóta er sífellt að að festast betur í sessi. VMS töflurnar eru orðnar eðlilegur partur af daglegri störfum flestra starfsmanna, allir ferlar í starfseminni hafa verið teiknaðir upp og eru rýndir reglulega af peim sem að vinna í peim par sem umbætur á peim eru leiðarljósið. Stór og smá umbótaverkefni sem oft skila góðum árangri eru reglulega unnin með aðlöguðu Kaizen verklagi sem hefur pótt henta vel. Innleiðingaráætlun er í gangi varðandi 5S og pví hefur 5S teymi par sem fulltrúar úr mismunandi deildum taka pátt verið starfrækt um nokkra hríð og stýrir pað innleiðingu á aðferðafræðinni innan fyrirtækisins. 5S hefur nú pegar verið innleitt á nokkrum stöðum bæði á skrifstofu fyrirtækisins, vöruhúsinu og í verksmiðjunni. pað er almenn ánægja meðal starfsmanna með árangurinn af peim $5 \mathrm{~S}$ innleiðingum sem pegar hafa átt sér stað og stefnt er að pví að $5 \mathrm{~S}$ verði innleitt á öllum svæðum í fyrirtækinu.

Mikið vantar pó enn upp á að nægilega margar aðferðir straumlínustjórnunar hafi verið innleiddar. SMED hefur verið til skoðunar hjá stjórnendum og tæknideild en innleiðing er ekki hafin og ýmis hugtök eins og Kanban og Heijunka virðast ekki vera almennt pekkt hjá starfsmönnum og ekkert er verið að vinna með pau.

Jújú maður hefur svosem eitthvað pælt í pessu Lean dæmi en petta eru einhver svaka fræði sem maður er ekkert að fara að setja sig neitt mikið inn í held ég..... alls konar einhver japönsk speki sem passar kannski ekkert endilega hér hjá okkur. Pað er samt margt sniðugt í pessu dóti eins og til dæmis töflurnar og 5 S. 42 VERKTAEKNI 2016/22
Samvinna á milli deilda og sviða hefur batnað mikið samkvæmt viðmælendum og mun meiri umbótahugsun en áđur var er almennt orðin ríkjandi á meðal starfsmanna. Mun fleiri starfsmenn eru farnir að taka virkan pátt í umbótaverkefnum og viðhorf til breytinga hefur gjörbreyst. Sumir starfsmenn tala um "Gamla Nóa" fyrir innleiðingu og „Nýja Nóa“ núna og pegar vel heppnaðar breytingar, eftirtektarverð samvinna eða umbótahugsun almennra starfsmanna eiga sér stað sem eru pessi hugtök gjarnan notuð.

Margt hefur áunnist en samt virðist vera að sé enn langt í land með að pekkingin á hugmyndafræði og aðferðafræði straumlínustjórnunar sé næg innan fyrirtækisins.

\section{Áhrif straumlínustjórnunar á vörugæði}

Erfitt er að greina hver áhrif innleiðingar straumlínustjórnunar hafa verið á vörugæði. Hlutfall kvartana frá viðskiptavinum hefur ekki minnkað, er ennpá á bilinu 100-120 kvartanir á hver 1.000 seld tonn sem er kannski ekki mjög mikið miðað við pær milljónir stykkja sem eru seldar á ári, en kvartanir eru teknar alvarlega hjá fyrirtækinu og vilji er til pess að fækka peim eins og kostur er. Hluti af framleiðslutækjunum er nokkuð gamall og á pað sinn pátt i að stundum er ekki hægt að hafa eins fullkomna stöðlun á framleiðslunni og æskilegt væri. Einnig er mikil handavinna við framleiðslu á sumum vörum, sérstaklega í kring um jól og páska og pá á sér stað mest af gæðafrávikum sem verða vegna mannlegra mistaka og leiða til kvartana frá viðskiptavinum. Unnið hefur verið töluvert að pví að auka gæðavitund starfsmanna innan fyrirtækisins með fræðslu og valddreifingu. Með peim hætti var farin sú leið að flytja meiri ábyrgð á gæðamálum á herðar framleiðslustjóra, verkstjóra og almennra starfsmanna og draga um leið úr formlegu gæðaeftirlit Viðmælendur voru ekki sammálu varðandi pað hvort pessi leið hafi skilað miklum árangri hingað til eða hvort sú leið sé vænleg til árangurs. Mjög skiptar skoðanir voru meðal viðmælenda um áhrif straumlínustjórnunar á vörugæði og ágæti peirrar leiðar sem farin hefur verið í peim málum. Sumum fannst petta afleitt.

Ég skil ekki hvað var verið að pæla með pví að leggja niður gæðaeftirlitið og setja petta bara allt á verkstjórana. Peir hafa ekki nógu mikla pekkingu eins og matvælafræðingarnir hafa...... Petta á bara eftir að koma í bakið á okkur.

\section{Öđrum fannst petta skref í rétta átt.}

раð var mikil framför að hætta með „gæðalögguna" og færa í staðin ábyrgðina á framleiðsluna beint. Pað eru allir núna miklu meðvitaðri um gæðamálin.....ég meina ef verkstjórarnir sem pekkja vöruna betur en allir aðrir eru ekki manna hæfastir til að gera petta, hver er pað pá?

\section{Stöðlun verklags}

Öll framleiðsluferli hafa verið teiknuð upp eins og önnur ferli í starfseminni. Vinnulýsingar hafa verið endurbættar, mælingar hafa verið samræmdar og reynt að staðla verklag eins og hægt er. Samt er ekki hægt að greina merkjanlegan mun á gallatî́ni pegar kemur að athugasemdum frá viðskiptavinum. Verklag á skráningu og meðferð meðferð kvartana hefur einnig verið staðlað Skráning og utanumhald kvartana er orðið miklu betra en áđur var í kjölfar umbótaverkefnis sem var unnið á pví ferli ásamt pví að athugasemdir varðandi vörur eða vörugæði sem koma frá neytendum á Facebook sídu fyrirtækisins eru núna skráđar. Par sem að bæði skráning og aðgengi neytenda til að koma athugasemdum á framfæri hefur gerbreyst er samanburðurinn á raunverulegri gallatíðni erfiður og par sem að skoðanir viðmælenda voru afar skiptar er ekki hægt að draga ályktanir um pað hvort að innleiðing straumlínustjórnunar hafi aukið vörugæði. 


\section{Áhrif Straumlínustjórnunar á starfsánægju}

Strax í upphafi var mikil tortryggni á meðal almennra starfsmanna í garð innleiðingarinnar og rádgjafans sem stýrði innleiðingunni. pekkingin á straumlínustjórnun var lítil sem engin innan fyrirtækisins og ekki unnið nógu markvisst að fræðslu og kynningu meðal almennra starfsmanna. Óvissan var pví mjög mikil og ástandið á atvinnumarkaðinum og í efnahagslífinu var ekki til auka almenna tiltrú starfsmanna á verkefninu og jók á óöryggið sem einhverjir fundu fyrir.

Ókei sko, pað er kannski allt í lagi að segja petta núna....en ef pað hefði verið einhver séns að fá sæmilega vinnu á pessum tíma hefði ég trúlega og ábyggilega fleiri bara labbað út...ég meina petta var bara eins og eitthvað tómt rugl. Maður purfti að sitja endalaust á einhverjum fundum með ykkur (stjórnendum) og [rádgjafanum] og setja einhverjar hugmyndir á gula miða sem maður vissi síðan ekkert hvort eitthvað kæmi út úr. Maður hafði auðvitað engan tíma til að standa í pessu ... pað var nógu brjálað að gera samt.

Fyrirtækið var skyndilega að taka mjög hröðum breytingum eftir að hafa verið frekar íhaldssamt í stjórnunarháttum og stöđugt í áratugi. Margir starfsmenn héldu að straumlínustjórnun væri fyrst og fremst leið til að fækka starfsfólki og sáu ekki tilganginn í pví að taka pátt í vinnu sem myndi jafnvel leiða til pess að pað missti starf sitt í framtídinni.

Ég meina, maður var náttúrulega skíthræddur fyrst um að pað ætti аð fara einhver massífur niðurskurður í gang. Ég man pað var líka talað um pað á göngunum að pað ætti að henda út öllu gamla liðinu og ráða inn yngra fólk í staðinn til að spara.

Pegar öldurnar lægði og starfsmenn fóru að átta sig á pví að markmið stjórnenda fyrirtækisins með pví að innleiða straumlínustjórnun í starfsemina var ekki að fækka störfum, heldur að ná betri árangri í rekstrinum breyttist viðhorfið jafnt og pétt á meðal peirra og mæld starfsánægja hefur síðan aukist jafnt og pétt með hverju ári og nú talsvert fyrir ofan meðallag hjá Íslenskum fyrirtækjum.

Ég held að mórallinn hafi aldrei verið eins góður og hann er núna, að minnsta kosti ekki sem ég man eftir. Раð eru allir eitthvað svo mikið til í að vinna saman alltaf og samvinna á milli sölu og framleiðslu er náttúrulega allt önnur en hún var áður.

Einn af peim páttum sem flestir viðmælendur nefndu varðandi aukna starfsánægju var bætt upplýsingaflæði innan fyrirtækisins. Notkun á VMS töflunum er stór páttur í gagnvirku upplýsingaflæði á milli deilda og starfsmanna.auk pess að vera aðalverkfæri verkefnastjórnunar innan fyrirtækisins.

Pað er alveg frábært að geta séð hvað er í gangi hjá öðrum deildum með pví bara að kíkja á töflurnar peirra og skoða verkefnin sem hanga uppi. Раð er bara verst аð pað fatta ekki allir að gera petta eða ég held líka að sumir kunna ekki við аð vera аð skoða töflurnar hjá öðrum eins og pað sé hnýsni eða eitthvað.

Mikið hefur verið unnið að umbótum á upplýsingaflæði innan fyrirtækisins. VMS töflurnar gegna par veigamiklu hlutverki par sem að pær eru sýnilegar öllum starfsmönnum. Viðmælendur voru almennt sammála um pað аð upplýsingaflæði hefi batnað verulega innan fyrirtækisins.

Fyrsta stóra Kaizen verkefnið var mjög metnaðarfullt, sérstaklega í ljósi pess að pekkingin á aðferðafræði straumlínustjórnunar var mjög takmörkuð innan fyrirtækisins. Markmiðið var að bæta afhendingarhlutfall á vörum fyrirtækisins til viðskiptavina með pví að innleiða nýtt áætlanakerfi og ný vinnubrögð í allri virðiskeðjunni varðandi framkvæmd söluáætlana, innkaupa og skipulagningar framleiðslu.

Áður en pað var farið í áætlanaverkefnið voru níu manns minnir mig að sjá um einhverskonar innkaup án pess að pað væri endilega peirra hlutverk eða djobb. (ísl.starf). Pældu i pví. níu manneskjur! Og samt var innkaupadeild. Núna eru pær tvær og allt gengur miklu betur.
Petta fyrsta Kaizen verkefni sem var unnið hafði mjög mikil áhrif á alla starfsemi og árangur fyrirtækisins. Vinnubrögð við áætlanagerð og framleiðsluskipulag gerbreyttist og skerpt var á ábyrgð allra sem koma að ferlinu. Afhendingarhlutfallið á vörum til viðskiptavina fór úr pví að vera yfirleitt á bilinu 70-80 \% í pað að vera nánast alltaf yfir 90\% í flestum vöruflokkum og marga mánuði er pað nær 100\%.

Petta er orðin rosa breyting. Pað er sko ekkert einfalt mál að eiga alltaf allt til hjá fyrirtæki sem er með langt yfir prjúhundruð mismunandi vörur í boði og ábyggilega miklu meira en púsund vörunúmer í umbúðum og hráefnum. Ég meina pað er rosalega margt sem parf alltaf að ganga upp til að petta sé hægt....á hverjum einasta degi.

Petta aukna pjónustustig gagnvart viðskiptavinum hefur ekki leitt til aukinnar birgðasöfnunar pví að á tímabilinu hefur veltuhraði birgða framleiðsluvara aukist sem bendir til pess að flæðið sé skilvirkara en pað var áður og meira sé verið að miða framleiðsluna til að uppfylla raunverulega pörf en ekki til að nýta vélar tíma eða aðföng eins og pægilegast gæti pótt hverju sinni.

Við vorum alltaf að lenda í pví að lagerinn var fullur af vörum en samt ekkert til ef pú skilur hvað ég meina. Allt of mikið til af vörum sem hreyfðust lítið og runnu svo kannski út fyrir rest en vinsælu vörurnar á bullandi vöntun og allir brjálaðir, (x) var að koma hlaupandi inn og stóð yfir okkur á meðan við vorum að pakka einhverju sem hann beið eftir (...). Endalaust verið að redda einhverju og skipta um í vélum til að bjarga einhverjum slöttum pú veist...

Sá tími sem líour frá pví að hugmynd að nýrri vöru er sampykkt og par til hún kemur á markað hefur styst verulega og allt ferlið orðið "margfalt skilvirkara og tíu sinnum skemmtilegra" eins og einn viðmælandi orðað pað.

Vörupróun á nýjum vörum hefur tekið stakkaskiptum hjá fyrirtækinu. Próunartíminn á nýjum hefur styst, samvinna á milli markaðs og sölusviðs og framleiðslusviðs í vörupróunarverkefnum hefur gerbreyst, öll undirbúningsvinna orðin vandaðri og allir pátttakendur í ferlinu eru orðnir mun betur upplýstir á öllum stigum vörupróunarferilsins.

Hérna í gamla daga pá frétti maður stundum af pví að pað ætti að fara að framleiða nýja vöru pegar umbúðirnar komu í hús eða maður sá hana auglýsta í einhverju blaði eins og einu sinni skeði. Pað var ekki einu sinni búið að spyrja mann hvort petta væri yfirhöfuð hægt eða hvort pað væri einhver tími til að gera petta.... Petta er allt öðruvísi núna maður... (X) er аuðvitað líka frábær í að stýra vörupróuninni og vinna petta með okkur. Pað er eins og petta á auðvitað að vera.

\section{Umræður og ályktanir}

Niðurstöður rannsóknarinnar leiða í ljós ýmsa annmarka á innleiðingunni en jafnframt er niðurstaðan sú að talsvert hefur einnig áunnist og er upplifun viðmælenda almennt sú að árangur hafi aukist á mörgum sviðum starfseminnar og eins að starfsánægja og samvinna hafi batnað innan fyrirtækisins.

Lítil og meðalstór fyrirtæki purfa að glíma við ýmis konar vandamál við innleiðingu straumlínustjórnunar bæði hvað varðar fjármögnun og stjórnunarlega annmarka (Achanga et al. 2006). Við innleiðingu straumlínustjórnunar hjá Nóa Síríusi var farin sú leið að fjárfesta í pví fá utanaðkomandi rádgjafa til að aðstoða við innleiðinguna trúlegt má telja að pað hafi gert gæfumuninn í pví að tekist hefur að innleiða straumlínustjórnun að nokkru leiti í starfsemina. Eitt af pví sem niðurstöður viðtalanna leiddu í ljós er pað að kynning á pví um hvað straumlínustjórnun snýst og hver sé tilgangurinn er ákaflega mikilvægt við fyrstu skref innleiðingar. Fyrstu skrefin sköpuðu ótta og óöryggi á meðal starfsmanna að sögn flestra viðmælenda og tafði pað fyrir pví að sá árangur næðist sem stefnt var að í fyrstu verkefnunum. Mun meiri skuldbindingu allra stjórnenda við verkefnið hefði purft og eins leiddi skortur á upplýsingaflæði og fræðslu til pess að innleiðingin gekk hægar en annars hefði trúlega orðið. 
Tengingin við vörugæði er ekki nægilega skýr hvorki í hugum viðmælenda né í mælanlegum árangri innan fyrirtækisins og hugmyndin sem lagt var upp með af stjórnendum fyrirtækisins um aukna gæðavitund samfara aukinni valdeflingu starfsfólks virðist enn eiga langt í land. Ekki allir viðmælenda sáu pessa tengingu straumlínustjórnunar við vörugæði og sumir sáu neikvæð áhrif á vörugæði. Breytt verklag við skráningar á gæðafrávikum skekkja par að auki myndina töluvert pannig að að ekki er hægt að fullyrða með neinni vissu um hver áhrifin hafa verið. Gæðamál voru flestum viðmælendum ofarlega í huga og bar pau oft á góma og gætti ákveðinna vonbrigða hjá sumum peirra með að árangurinn væri ekki mælanlega betri. Mögulega parf að skýra betur innan fyrirtækisins tengingu straumlínustjórnunar við gæðamál, hvernig hægt er að beita henni til að ná árangri í peim efnum og etja skýr markmið par um.

Innleiðing straumlínustjórnunar virðist hafa haft jákvæð áhrif á starfsánægju, prátt fyrir að svör viðmælenda bendi eindregið til pess að í upphafi hafi áhrifin verið neikvæð. Petta kom fram hjá viðmælendum og eins sýna niðurstöður starfsánægjukannana bættan árangur í pessum efnum á undanförnum árum Petta undirstrikar mikilvægi pess að kynna vel fyrir starfsfólki hugmyndafræði og aðferðafræði straumlínustjórnunar strax í byrjun innleiðingar en byrja ekki að innleiða verkfærin og sjá svo til með kynninguna eins og gert var í upphafi innleiðingarinnar hjá fyrirtækinu. Einnig kemur skýrt fram hve mikilvæg pekking stjórnenda á straumlínustjórnun er og stuðningur peirra við innleiðinguna parf að vera skýr og eindreginn strax frá upphafi.

Mestur árangur hefur náðst varðandi flæði í gegn um virðiskeðjuna. Afhendingarhlutfall á vörum til viðskiptavina hefur batnað verulega og einhverjir viðmælendur nefndu aukna ánægju viðskiptavina sem beina afleiðingu af pví. Afhendingartími á framleiðsluvörum hefur styst og vörupróun er orðin mun skilvirkari og markvissari. Birgðir hafa ekki aukist, hvorki í umbúðum og hráefnum né í framleiðsluvörum prátt fyrir stórbætt afhendingarhlutfall til viðskiptavina sem pýðir að veltuhraði birgða hefur aukist sem afleiðing af pví að ferlar eru orðnir skilvirkari. Skýr tenging er einnig hjá viðmælendum varðandi samband bætts flæðis við aukna starfsánægju og bætt samstarf á milli deilda og sviða.

\section{Lokaord}

Innleiðing straumlínustjórnunar hjá Nóa Síríusi er gott dæmi um pað hversu löng og ströng vegferð pað er fyrir minni fyrirtæki að tileinka sér aðferðafræðina. Prátt fyrir fullan stuðning forstjóra og stjórnar og mikla skuldbindingu við verkefnið bæði í fjármunum og tíma starfsmanna, einkum stjórnenda hafa hindranir verið margar. Niðurstöður rannsóknarinnar passa vel við ýmsar fyrri rannsóknir og undirstrika enn frekar mikilvægi pess að huga vel að peim páttum sem nauðsynlegir eru fyrir farsæla innleiðingu straumlínustjórnunar. Sérstaklega parf að tryggja næga pekkingu og skuldbindingu allra stjórnenda við verkefnið og pjálfun starfsmanna og upplýsingagjöf til peirra. Um pessar mundir er verið að setja aukinn kraft í innleiðinguna, bæði með ráðningu sérfræðings og stóraukinni pjálfun starfsmanna, Ljóst er að fyrirtækið á enn langt í land með pað að vera „LEAN“ prátt fyrir að margt hafi áunnist en skuldbindingin innan fyrirtækisins við verkefnið hefur aukist og stefnan er sú að komast lengra í átt að pví að vera straumlínufyrirtæki.

\section{Heimildaskrá}

(án dags.). Sótt 29. nov 2014 frá www.noi.is: http://noi.is/Um_Noa_Sirius/Um_ Noa_Sirius

Abdulmalek, F. A., \& Rajgopal, J. (28. nov 2006). Analyzing the benefits of lean manufacturing and value stream mapping via simulation: A process sector case study. International Journal of production economics, 107, 223-236. doi:10.1016/j.ijpe.2006.09.009
Achanga, P., Shehab, E., Roy, R., \& Nelder, G. (2006). Critical success factors for lean implementation within SME's. Journal of Manufacturing Technology Management, 17(4), 460-471. Sótt 20. feb 2015

Bayo-Moriones, A., Bello-Pintado, A., \& de Cerio, J. M.-D. (2010). 5S use in manufacturing plants: contextual factors and impact on operating performance. The International Journal of Quality \& Reliability Management, 27(2), 217-230. doi:http://dx.doi.org/10.1108/02656711011014320

Bhasin, S., \& Burcher, P. (2006). Lean viewed as a philosophy. Journal of Manufacturing Technology Management, 17(1/2), 56-72. Sótt 13. feb 2015 frá http://search.proquest.com/docview/208185115?accountid=32710

Brunet, A. P., \& New, S. (2003). Kaizen in Japan: an empirical study. International Journal of Operations \& Production Management, 23(11/12), 1426-1446. Sótt 16. feb 2015 frá http://search.proquest.com/docview/232351270?acc ountid $=32710$

Brynja B. Gröndal. (2013). Starfsánægja í straumlínustjórnun. Rannsókn á viðhorfum starfsmanna til innleiðingar straumlínustjórnunar og áhrifum hennar á starfsumhverfi, störf og starfsánægju. Óbirt MS-ritgerð: Háskóli Íslands, Viðskiptafræðideild, Reykjavík.

Chiarini, A. (2013). Lean Organization: from the Tools of the Toyota Production System to Lean Office. Milan: Springer-Verlag Italia.

Coleman, B. J., \& Vaghefi, M. R. (1994). Heijunka (?): A key to the toyota production system. Production and Inventory Management Journal, 35(4), 31-35. Sótt 18. okt 2015 frá http://search.proquest.com/docview/1998772 14 ? accountid= 32710

Commission of the European Communities. (2005). FOOD PRICES IN EUROPE. Brussel: Commission of the European Communities. Sótt 23. feb 2015 frá http://eur-lex.europa.eu/legal-content/EN/TXT/PDF/?uri=CELEX:52008DC $0821 \&$ from $=\mathrm{EN}$

Dahlgaard, J. J., \& Dahlgaard-Park, S. M. (2006). Lean production, six sigma quality, TQM and company culture. The TQM Magazine, 18(3), 263-281. doi:http://dx.doi.org/10.1108/09544780610659998

Dora, M., Kumar, M., Van Goubergen, D., Molnar, A., \& Gellynck, X. (2013). Operational performance and critical success factors of lean manufacturing in European food processing SMEs. Trends in Food Science \& Technology, 31, 156-164.

Dora, M., Van Goubergen, D., Molnar, A., Gellnyck, X., \& Kumar, M. (2012). Adoptability of Lean Manufacturing among Small and Medium Food Processing Enterprises. IIE Annual Conference.Proceedings, (bls. 1-9). Sótt 24. okt 2015 frá http://search.proquest.com/docview/1151086083?accoun tid $=32710$

Helga Jónsdóttir. (2013). Viðtöl í eigindlegum og megindlegum rannsóknum. Í Sigríður Halldórsdóttir (Ritstj.), Handbók í aðferðafræði rannsókna (bls. 137-153). Akureyri: Ásprent Stíll.

Hines, P., \& Rich, N. (1997). The seven value stream mapping tools. International Journal of Operations, 17(1), 46-64. Sótt 26. jan 2015 frá http://dx.doi. org/10.1108/01443579710157989

Hines, P., Holwe, M., \& Rich, N. (2004). Learning to evolve: A review of contemporary lean thinking. International Journal of Operations \& Production Management, 24(9/10), 994-1011. Sótt 13. feb 2015 frá http:// search.proquest.com/docview/232364114? accountid=32710

Holweg, M. (2007). The genealogy of lean production. Journal of Operations Management(25), 420-437. doi:10.1016/j.jom.2006.04.001

Jacobsen, G. (ágúst 2013). Comparisons Of Labour Productivity And Per Capita Income In The Nordic Countries (2000-2010). International Business \& Economics Research Journal, 12(8), 945-952. Sótt 22. feb 2015 frá http:// cluteinstitute.com/ojs/index.php/IBER/article/view/7990/8044

Katrín Blöndal, \& Sigríður Halldórsdóttir. (2013). Úrtök og úrtaksaðferðir í eigindlegum rannsóknum. Í Sigríour Halldórsdóttir (Ritstj.), Handbók i aðferðafæði rannsókna (bls. 129-136). Akureyri: Ásprent Stíll.

Kristín Pórarinsdóttir, \& Rúnar Sigpórsson. (2013). Starfenda og Pátttökurannsóknir. í S. Halldórsdóttir (Ritstj.), Handbók i aðferðafræði rannsókna (bls. 347-359). Akureyri: Stíll Ásprent.

Liker, J., \& Morgan, J. M. (2006). The Toyota Way in Services: The Case of Lean Product Development. The Academy of Management perspectives, 20(2), 5-20. doi:10.5465/AMP.2006.20591002

Melton, T. (2005). The Benefits of Lean Manufacturing: What Lean Thinking has to Offer the Process Industries. Chemical Engineering Research and Design, 83(6), 662-673. doi:doi:10.1205/cherd.04351

Ólöf Árnadóttir. (2010). Straumlínustjórnun í ílenskum fyrirtækjum : valkostur fyrir heilbriðgðispjónustuna? Óbirt MS-ritgerð: Háskólinn á Bifröst, Viðskiptadeild, Bifröst. Sótt 12. okt2015 frá http://hdl.handle.net/1946/7895

Robson, C. (2011). Real world research: A resource for users of social research methods in applied settings (3. útg.). Chichester: John Wiley \& Sons Ltd.

Rúnar Helgi Andrason, \& Ársæll Már Arnarsson. (2013). Tilfellarannsóknir. Í Sigríður Halldórsdóttir (Ritstj.), Handbók í aðferðafræði rannsókna (bls. 
497-509). Akureyri: Ásprent Stíll.

Sigríður Halldórsdóttir. (2013). Yfirlit yfir eigindlegar rannsóknaraðferðir. Handbók í aðferðafræði rannsókna (bls. 239-249). Akureyri: Áprent Stíll.

Sigríður Halldórsdóttir, \& Sigurlína Davíósdóttir. (2013). Réttmæti og áreiðanleiki í megindlegum og eigindlegum rannsóknum. Í Sigrî́our Halldórsdóttir (Ritstj.), Handbók i aðferðafræði rannsókna (bls. 211-227). Akureyri: Ásprent Stíll.

Slack, N., Chambers, S., \& Johnston, R. (2010). Operations Management (6. útg.). Harlow: Pearson Education.

Snorri Fannar Guð̌laugsson. (2013). Straumlínustjórnun i íslensku fjármálakerfi. Er hægt að nota straumlínustjórnun til að ná betri árangri í íslensku fjármálakerfi? Óbirt MS-ritgerð: Háskóli íslands, Viðskiptafræðideild, Reykjavík. Sótt 15. okt 2015 frá http://hdl.handle.net/1946/13689
Unnur Guðrún Óttarsdóttir. (2013). Grunduð kenning og teiknaðar skýringarmyndir. Í S. Halldórsdóttir (Ritstj.), Handbók i aðferðafræði rannsókna (bls. 361-375). Akureyri: Ásprent Stíll.

Vilborg Hannesdóttir. (2009). Próun og pjálfun starfsmanna ístraumlínustjórnun. Óbirt MS-ritgerð: Háskóli Íslands, Viðskiptafræðideild, Reykjavík. Sótt 20. feb 2015 frá http://skemman.is/handle/1946/2524

Womack, J. P., \& Jones, D. T. (2003). Lean Thinking. New York: Free Press.

Womack, J. P., Jones, D. T., \& Roos, D. (2007). The Machine That Changed the World. New York: Free Press.

Worley, J. M., \& Doolen, T. L. (2006). The role of communication and management support in a lean manufacturing implementation. Management Decision, 44(2), 228-245. Sótt 10. okt 2015 frá http://search. proquest.com/docview/212073699? accountid=27513 